\title{
David DEVINS - Brian JONES \\ STRATEGY FOR SUCCESSION IN FAMILY OWNED SMALL BUSINESSES AS A WICKED PROBLEM TO BE TAMED
}

Contemporary strategic-planning processes don't help family businesses cope with some of the big problems they face. Owner managers admit that they are confronted with issues, such as those associated with succession and inter-generational transfer that cannot be resolved merely by gathering additional data, defining issues more clearly, or breaking them down into small problems. Preparing for succession is often put off or ignored, many planning techniques don't generate fresh ideas and implementing solutions is often fraught with political peril. This paper presents a framework to explore the idea of wicked problems, its relevance to succession planning in family businesses and its implications for practice and policy.

A wicked problem has many and varied elements, and is complex as well as challenging. These problems are different to hard but ordinary problems, which people can solve in a finite time period by applying standard techniques. In this paper the authors argue that the wicked problem of family business succession requires a different approach to strategy, founded on social planning processes to engage multiple stakeholders and reconcile family/business interests to foster a joint commitment to possible ways of resolution. This requires academics and practitioners to re-frame traditional business strategic planning processes to achieve more sustainable family business futures.

\section{Keywords: family business, succession, strategy, strategic planning}

Family businesses are a long established, omnipresent business phenomenon operating in all industrial sectors and making a significant contribution to many local, regional and national economies across the globe. The European Union network of family businesses (EFB) representing long-term family owned enterprises estimates that there are more than 14 million that account for around 50\% of GDP and employ 60 million workers. In the UK alone the Institute for Family Businesses (IFB) referring to research by Oxford Economics suggest that family businesses contribute the equivalent of almost $10 \%$ of the Government's total tax receipts and employ almost twice as many workers as the entire public sector and five times as many as the large firms listed on the FTSE 100 (IFB, 2011; IFB 2008). Family businesses are by any measure an important element of most national economies however they are increasingly a concern to European policy makers who recognise the challenge of family business sustainability in the long run. This has led the EFB to identify the greatest challenge facing family businesses as the transfer of ownership and/or management of the business to the next generation which manifests itself in different ways in different European states.

In the UK, the Department for Business Innovation and Skills estimates that around 266,000 family firms anticipate closure and over 500,000 full transfer in the five years to 2018. A natural desire to keep the business within the family means business owners have to make decisions relating to when and how to transfer management and ownership of the company to the next generation. As with firms more generally, many family businesses will be looking to the future to build their business strategy in a world that is increasingly complex and both family leaders and their successors are accused of being culprits in succession failure with many failing to anticipate or plan for succession (Kraus et al., 2011; IFB, 2008).

In this paper we explore family business succession through the lens of business strategy and the extent to which the generic concepts and models of strategy are relevant to family businesses and can be conceived in the context of a turbulent and challenging internal and external environment. Management and ownership 
succession from one generation to the next represents a crucial strategic issue which many family businesses appear to put off or ignore (Hurst, 1995).

\section{Wicked problems and strategy}

It seems as though some problems are relatively easy to solve, such as factoring a quadratic equation, navigating a maze, and solving the tower of Hanoi puzzle (Newell - Simon, 1972). However, many problems in business are not quite so well defined in terms of their nature or the paths to be pursued to solve them. In fact many of the strategic challenges facing business are invariably 'wicked' in nature in that they persist and are subject to redefinition and resolution in different ways over time. Wicked problems are not objectively given but their formulation depends on the viewpoint of those presenting them. There is no ultimate test of the validity of a solution to a wicked problem as the testing of solutions takes place in some practical context and the solutions are not easily undone (Coyne, 2004).

The concept of a wicked problem emerged in the planning and design context when authors such as Rittel and Webber (1973) sought an alternative to the linear, step-by step model of the process being explored by many designers and design theorists at the time. Although there are many variations of the linear model, its proponents hold that the process is divided into two distinct phases: problem definition and problem solution. Problem definition is an analytic sequence in which the designer determines all of the elements of the problem and specifies all of the requirements that a successful design solution must have. Problem solution is a synthetic sequence in which the various requirements are combined and balanced against each other, yielding a final plan to be carried into production. In the abstract, such a model may appear attractive because it suggests a methodological precision that is, in its key features, independent from the perspective of the individual designer. However, critics were quick to point out two obvious points of weakness associated with this approach: one, the actual sequence of design thinking and decision making is not a simple linear process; and two, the problems addressed by designers do not, in actual practice, yield to any linear analysis and synthesis (Buchanan, 1992).

In order to address these shortcomings, we argue that succession problems need to be viewed as "wicked' in order to reflect the reality in which many smaller family businesses operate. Whilst there is no single settled definition of a wicked problem, these problems invariably occur in a social setting where there can be radically different views and understanding of the problem by different stakeholders with no 'unique and correct' view of them held by all (Horn - Weber, 2007). Thus their wicked nature stems from not only a biophysical complexity but also from multiple stakeholder perceptions and of potential trade-offs associated with problem solving (Batie, 2008). Termeer et al. (2013) have noted that it is difficult to define wicked problems "because the formulation of the problem is the problem; they are considered a symptom of another problem; they are highly resistant to solutions and extremely interconnected with other problems" (p. 27). Roberts (2000) emphasises the difficulty in formulating the problem that makes the search for solutions open ended, thus allowing competing stakeholders to promote solutions, which connect with their own problem definition. She also notes the complexity of the problem solving process due to a constantly changing context of political and resource-related issues.

\section{Towards a response to strategy}

The concept of the wicked problem sets the context for our discussion of the theory underlying the development of business strategy in the family business. Our view is influenced by the contribution of Mintzberg and his co-authors who have informed the strategy discourse over several decades. In the late 1970's, Mintzberg (1978) drew a distinction between deliberate and emergent strategy. For Mintzberg, the process of making strategy through an emergent process involves creating solutions that react to present problems and decisions made are done so on an incremental basis. Progress is made towards a goal through many small steps and strategy can be shaped, influenced, driven and determined by a range of stakeholders as much as by small management elites in the enterprise. This process is in essence an antidote to the more rational, structured, top-down approach to strategy proposed by a wide range of strategy thinkers which continues to heavily influence strategy development in large organisations more generally (Selznick, 1957; Chandler, 1962; Learned et al., 1965; Ansoff, 1991). Through analysis, using for example tools and techniques including benchmarking, competitor analysis, cost benefit analysis, critical success factors, life cycle concepts, market opportunity analysis, PEST (Political, Economics, Social, Technological) analysis, and SWOT (Strengths, Weaknesses, Opportunities and Threats) strategy can be developed and problems solved by gathering data, defining issues more clearly, identifying potential solutions and making choices (Frost, 2003).

The binary division of deliberate and emergent strategies provide useful conceptual tools of analysis but capturing the realities of strategies in the complex and fast changing real world requires a combination of the two approaches to capture in full the richness of 
business life as it actually occurs. Squaring the rational traditional strategic planning approach founded largely on research and practice in large businesses with the small business context and variables such as culture and politics is a complex area which can be challenging (Johnson et al., 2003). Mintzberg and those that follow him generally argue that in a fast changing world in which environmental turbulence requires faster, smarter and more intelligent responses, a flexible approach to strategy is a core requisite of a world in which change is a constant. Learning from experience and by what works in practice is perhaps emblematic of an emergent strategy and chimes with the dominant form of learning in smaller businesses and this provides a context for strategy for succession in the small family business operating in a complex internal and external environment.

In one of the few papers to address strategy as a wicked problem, Camillus (2008) suggests that it is the social complexity of wicked problems as much as their technical difficulties that make them tough to manage. He suggests that they crop up when organizations have to face constant change or unprecedented challenges where the greater the disagreement among stakeholders, the more wicked the problem is. Camillus (2008) notes that 'confusion, discord, and lack of progress are telltale signs that an issue might be wicked' (p. 2.). He identifies five characteristics of a wicked problem for strategy that can be used to illustrate the challenge of succession planning in the small family business context. These are summarised in Figure 1.

\section{Characteristics of wicked problems and strategy}

Figure 1

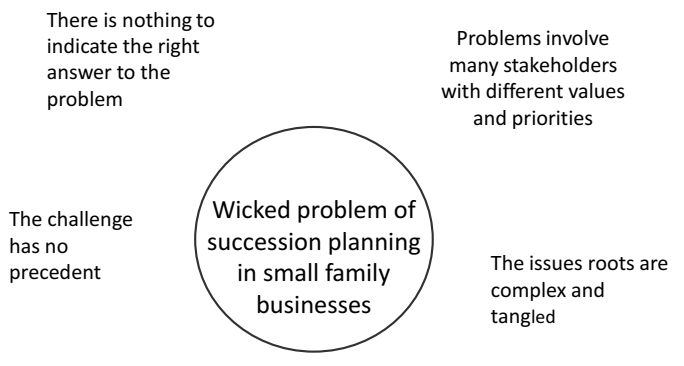

The problem is difficult to get to grips with and changes with every attempt to address it

Not all succession planning problems are wicked and for some family businesses the strategy for succession may be relatively straightforward with a clearly defined succession plan formulated and implemented. However for many businesses, family and non-family members will have different values and priorities, succession will have complicated, snarled and twisted roots, it will be difficult for founders, successors and others to grapple with and for many stakeholders they will be facing the specific context surrounding it for the first time. Stakeholders will be faced with identifying a number of alternatives for action, many of which will have uncertain outcomes that need to be assessed within the context of the small business where strategy is often enacted in a very different way to the planned and rational manner conceived in many academic textbooks.

\section{Strategy in the small family businesses}

The strategy process in the small business bears little or no resemblance to management processes found in larger organisations which have been the subject of substantial academic research resulting in numerous models, prescriptions and constructs (Jennings - Beaver, 1997). In the larger organisation, strategy is often created deliberately as a result of the pursuit of explicit policies designed to minimise costs or achieve product/service differentiation for example. Consequently, strategy becomes a primarily predictive process concerned with the clarification and communication of long term objectives, the formulation of policies to meet such objectives, the implementation of such policies and the feedback of information to evaluate success in the achievement of pre-determined goals. In contrast, strategy in the smaller business is more likely to accidentally arise as a result of the particular operating circumstances surrounding the enterprise. Here strategy becomes an emergent and adaptive process concerned with the manipulation of a limited amount of resources, usually in order to gain the maximum immediate and short-term advantage. In the small business, efforts are not concentrated on predicting and influencing the external environment but on adapting as quickly as possible to the changing demands of that environment and devising suitable tactics for mitigating the consequences of any threatening changes which occur (Jennings - Beaver, 1997).

In the largest organisations, the formulation of strategy can involve hundreds of stakeholders each representing the interests of their own organisation, division, department or profession and drawing on a range of expert knowledge in particular fields. Large businesses organised according to areas of functional expertise (for example, Human Resources, Marketing, Sales, Finance) engage with a range of stakeholders in specialist areas. This complex task involves networking, co-ordinating and managing dynamic relationships that require the formulation and delivery of strategy. The challenges of the tasks should not be underestimated as expert knowledge changes, roles and responsibilities shift, contacts and relationships move, and the ever constant 
drive for innovation and efficiencies force new patterns of working and consequently emergent strategy upon businesses. The nature of the stakeholder environment in large organisations as well as smaller family businesses present a number of ever present problems that verge on the wicked for the formulation, development and delivery of strategy. In the smallest firms all these roles and interests may be enacted by one or two people and the knowledge and skills of these individuals becomes a key factor in the development of small business strategy. Policy discourse in the UK emphasises poor management and leadership skills in the economy and particularly amongst smaller businesses. For example research by the London School of Economics argues that across many countries family businesses are the worst managed type of business (Bloom et al., 2012). There are often calls from researchers and policy makers for the 'professionalisation' of leadership and management in smaller enterprises to improve business strategy. Researchers such as Breton-Miller and Miller (2009) suggest that family businesses are slower and more reluctant to professionalise than non-family businesses, particularly in terms of hiring external managers or seeking external advice and support (from both business support organisations and non-executive directors), while the lack of external shareholders results in less pressure to challenge how the family runs the business.

Strategy in smaller businesses is often practiced instinctively and is seldom a readily visible process (Jennings - Beaver, 1997). This has contributed to researchers identifying a lack of strategic planning as a key mechanism to counteract underinvestment, encourage investment and lead to the sustainability and growth of family firms (Eddleston et al., 2013; Chrisman et al., 2003). Researchers have noted how the familial element of the business acts as a barrier to wider stakeholder engagement when strategic decisions are made away from the workplace and without non-family input (Cunningham et al., 2015). In addition, many small firms lack the resources to conduct strategic planning as a rational, information intensive or discrete process and a range of interwoven business and family objectives add a layer of complexity that is often absent in non-family businesses. This additional complexity is illustrated through the concepts of socio-emotional wealth, heterogeneity and familiness discussed below.

\section{Socio-emotional wealth}

The concept of socio-emotional wealth (SEW) has been used increasingly to explain and predict differences between family and non-family firms. Adopting this analytical lens, business success in economic terms is balanced with family considerations and wider social standing in the local community. From this perspective, family owners are frequently viewed to be conservative in relation to risk, innovation or growth that may threaten the business whilst building up the social capital of the business, which tends to lead to stronger relationships with trading partners, advisers and employees as well as within the family itself. Research suggests that the aversion to risk may manifest itself in a number of ways including lower ratios of debt to equity and debt to assets and higher levels of liquidity (Gonzalez et al., 2013; Bigelli - Sánchez-Vidal, 2012). It is argued that this leads to longer time horizons for financial planning purposes facilitating longer-term investment in the business, rather than pursuit of short-term profits for dividends. For this reason, while family businesses may appear to be growing more slowly than non-family ones, longer term that gap may close, as the family business continues its sustainable growth route (Miller - Le Breton-Miller, 2005; Wilson et al., 2013). However, this view runs somewhat counter to the prevailing view of the shorter planning horizons often associated with smaller businesses more generally (Jennings - Beaver, 1997) and may be at least partly explained by the heterogeneity that is increasingly recognised as a characteristic of family businesses (Westhead - Howarth, 2007; Chua et al., 2012).

\section{Heterogeneity}

If detecting strategy in small family firms is difficult, so too is generalising approaches across the small family business population. One of the main criticisms in relation to family business research refers to the inappropriate treatment of them as a homogenous group. Researchers are increasingly aware of the importance of recognising potential sources of heterogeneity among family firms that may include leadership goals (Chrisman et al., 2012), governance structures (Carney, 2005) and resources (Habbershon et al., 2003). One of the areas often contested is the relative economic performance of family and non-family firms and the balance between economic and non-economic objectives of family firms. Family owners can be seen as the stewards or custodians of the business and that implies a different set of success criteria, rather than the straightforward profitability or shareholder value often associated with many larger private sector enterprises. These criteria can include providing employment opportunities for family members, both currently (Kellermanns et al., 2008) and in the future (Miller - Le Breton-Miller, 2003), running the business in such a manner as to reflect well on the social contribution made by family owners (Berrone et al., 2012) and preserving family wealth (Chrisman et al., 2003).

Family businesses differ in the degree of family involvement and leadership and management in the busi- 
ness. Some families will take a role in the day to day running of the business whilst others will take a more hands-off approach and involve professional non-family managers. Some will pursue profit maximisation whilst others will follow a more balanced and sustainable approach to business strategy which takes social and environmental concerns into consideration. Long-term business sustainability requires retaining well-trained staff who buy in to the business and feel a sense of engagement or 'ownership' and share the objectives (and successes) of the family. This requires the family owners to recruit carefully, so the employees fit in with the team and the ethos of the business, and treat the staff well to reinforce these values. This may include, for example, and when compared with non-family businesses, a greater commitment to training, a stronger tendency to retain employees during a downturn, higher wages or long-term non-pecuniary benefits such as health insurance, and a smaller salary gap between employees and owner-managers (Miller - Le Breton-Miller, 2005).

\section{Familiness}

A defining characteristic of family firms is the interplay between business and family interests that impact on their strategic planning processes. The concept of 'familiness' is offered as an explanation for both the superior and sub-optimal performance of family firms. Familiness overlaps with the corporate culture of a family business, as the founder's and founder's descendants' own values, beliefs, assumptions, and attitudes are absorbed in the corporate culture and influence the way things are done in the business (Barney, 1986). Familiness is created by the interactions between the founder, family members, generations of the family, and the business. This can be a source of strength of the business but it is not always a positive influence. For example, if familiness is not maintained and nurtured, it can rapidly become a destructive force. For this reason Habbershon and Williams (1999) distinguish between distinctive and constrictive familiness, where constrictive familiness develops when founder and family capital are eroded and family involvement becomes an encumbrance to the family business and distinctive familiness exists when family involvement in a business provides a firm with a sustainable competitive advantage. In a similar way Arregle et al. (2012) argue that a family's discretion over strategy and access to resources are very different for family controlled and family-influenced businesses. For example, it is argued that in family-influenced firms access to resources for non-family stakeholders is more open in terms of for example ownership or representation on the board governing the enterprise while in family controlled enterprises this is not necessary the case.
These factors contribute to the dynamic and complex family business context within which strategy is developed and enacted. A range of family and non-family stakeholders can have different values and priorities; familiness exerts a considerable influence on business strategy which tends to be instinctive and adaptive rather than a deliberate discrete process and some researchers and policy makers emphasize a deficiency of leadership and management capability that contributes to the lack of succession planning in many family businesses.

\section{The Case of succession planning as a wicked problem}

The problem of succession and the need for strategic planning is widely acknowledged in the family business literature. For example, Eddleston et al. (2013) argue that family businesses in different generational management stages will have different needs with respect to both strategic planning and succession planning. Furthermore, founders who are most interested in perpetuating their legacy and maintaining their family's control of the business are most likely to develop a plan for succession. The deliberate development of a succession plan features strongly in some of the literature and it is argued by some that firms with succession plans should achieve greater firm growth than those that lack such plans. For example, Craig and Moores (2005) suggest that without succession plans, professionalization of the family business is seriously inhibited and an opportunity to address sub-optimal performance that is the result of appointments and promotions of staff or workers that are made on the basis of birth or personal friendship rather than on the basis of ability, education and or technical qualifications are missed. There is clearly some intuitive logic associated with the extent to which those businesses that deliberately plan for growth are more likely to achieve growth and that more skilled and capable workers may be required to address sub-optimal working. However, as we have indicated previously, family businesses are likely to pursue social as well as economic performance objectives and these need to be taken into account in the treatment of succession.

\section{Succession as a complex process}

On the surface, the development of a strategy to solve the problem of succession can be viewed as a relatively straightforward event, the moment when a successor takes over as the Chief Executive of a family business or where 'the baton' is passed to the next generation (Dyck et al., 2002; Mitchell et al., 2009). However, this instantaneous view of succession is challenged by many researchers who hint at the wicked nature of the 
problem arguing that succession is often a lengthy and uncertain process. Jaffe (2005) notes that it is important to recognise that as life spans and careers lengthen, so do the number of years the two or even three generations of a family work together in the business. This view also recognises that succession is more than just about one leader but rather about developing a team for future success when the talent is dispersed in the family or between several non-family workers. Some bring a sense of analytical order to what has been recognised by others as a chaotic process (Watson, 1994). Stavrou and Swiercz (1998) view the process of succession as three distinct stages: (i) pre-entry, where the designated or potential successor(s) are prepared or 'groomed' to take over; (ii) entry, involving the integration of the successor(s) into business operations; and, (iii) finally, promotion to a management position. Whilst this analysis provides an insight into succession as a staged process, it does little to illuminate the social complexity of management transition that is the everyday reality for many smaller family businesses.

There is almost universal agreement that a well-developed succession plan is seen to be a crucial element in successful transfer and succession in the family business and some researchers have identified good practice to support the process. This includes preparing the next generation as soon as possible for succession and developing a formalised succession plan with and agreed by all family business stakeholders (including influential non-family members) (Lansberg, 1988). However these researchers also hint at the wicked nature of succession planning in terms navigating the complex and uncertain waters of relationships between family members and non-family members, reconciling visions and values, reluctance of the older generation to step aside or a younger generation to enter the business and the lack of a precedent to follow.

\section{Implications of familiness}

It is the culture and how the concept of familiness is manifested in family businesses that will often contribute to the wicked nature of succession planning. Nordqvist (2011) argues that the key to understand why family firms may be special cases of strategic management is likely to be found at the micro level of social interaction. At this level, everyday interplay and mutual influence of the family and the business are expressed through family and non-family actors who impact the strategy process, as well as where and how these actors interact. In common with strategy more generally, the strength of the leadership vision and the extent to which the family and non-family members are bought into the vision are identified as important factors in successful transitions (Barnett et al., 2012). However, the familiness of many business results in a multi-faceted social environment that introduces complexity in interpersonal and group dynamics, which can result in a range of relational factors that impede the succession process. Sibling or cousin rivalries, conjugal problems, ownership dispersion issues and family altruism are all potential causes of uncertainty in the family business strategic context. Family business members, especially business founders and successors, play different roles in the business and at home and multiple identities have to be traversed and reconciled (Chrisman et al., 2008). The different roles, multiplied by different individual and multi-entity roles, and the underlying needs, values and agenda of each role, make the family business a chaotic organisation during the succession process where family business succession can be considered to be a dynamic, social process between business founders, successors and other stakeholders (Lam, 2011; Watson, 1994).

The strategic needs of the business and what the family wants are not easily reconciled in the process of succession and succession planning. This has led some to argue that financial planning for the future of a family business must include consideration of two dimensions - the family's desires and intentions for the business, and strategic planning processes for the business future (Jaffe, 2005). Jaffe puts forward the idea of a planning process based on a board of directors and a family council to reconcile different interests and to set strategy. The model is seen to help the family negotiate the boundary between the world of the family and the world of the business. However, the two worlds are not always easy to navigate or negotiate as they are often interwoven and the idea of a family council and board of directors is unlikely to suit all family businesses, particularly the many smaller ones that are renowned for the informality of their governance structures. Trying to reconcile the competing needs and demands of family and business and of different family members is not something that is easy to achieve and it is important to take account of expectations of the business and of family life with regard to strategies for succession planning. The frequency and magnitude of conflict has been found to increase with the number of closely affiliated family members with organisational roles, the number of non-involved family members who can affect business decisions and the strength of the founder's shadow cast over the business (Davis - Harveston, 1999; Memili et al., 2013).

\section{Leadership characteristics}

Several studies have focussed in the personal, emotional and developmental characteristics of the founder-owner and their role in the succession process 
(Levinson et al., 1978). The inability on the part of the founder of the business to let go and a lack of trust and motivation on the part of the successors or other family members are identified as key relational factors that contribute to the wickedness of the succession process (Bjornberg - Nicholson, 2012; De Massis et al., 2008). The family business leader is subject to a number of competing and conflicting business and family influences that may cause dissonance leading to erratic and unpredictable behaviour, which is in complete contrast to the rational, professional and acceptable management role portrayed by Mintzberg (1973) and others. A study undertaken by Lam (2011) suggests that many business founders are reluctant to seek external professional advice in the process of family business succession: many do not see the value and rationale behind it, while others feel that it demonstrates their incompetence to lead a family and hand over the business to the next generation.

Within the context of transition, Lansberg (1988) labelled a phenomenon as the succession conspiracy when observing that not only is the incumbent leader often reluctant to retire, but those employees, family members, customers, suppliers, and other key stakeholders close to the founder encourage such reluctance. This conspiracy means that the plan for retirement is often placed on hold and goes part way to explaining why so many family business owners fail to set out a clear succession plan.

\section{Implications of SEW}

Research has also emphasised more diverse pathways of succession, looking through the prism of what exactly SEW means. For example, while transferring the business itself to a family member might be seen as ideal, not doing so should not necessarily be seen as a failure. For example, transferring the physical entity of the business itself may be less crucial than the transfer of its core values, such as entrepreneurial spirit, or of creating opportunities in general for the next generation (Salvato et al., 2010). This opens up a variety of potential avenues for succession beyond the traditional founder-family member succession that tends to dominate the discourse. As DeTienne and Chirico (2013) note, family members may exit one business entity and simply redeploy resources into other business activities to suit their wider family-business interests at a given time.

\section{Towards a framework}

Our discussion leads us towards the development of a framework to illustrate the key characteristics of succession planning in small family businesses and the wicked problem that it presents for strategy (Figure 2).

\section{Characteristics of the wicked problem of succession planning in small family businesses}

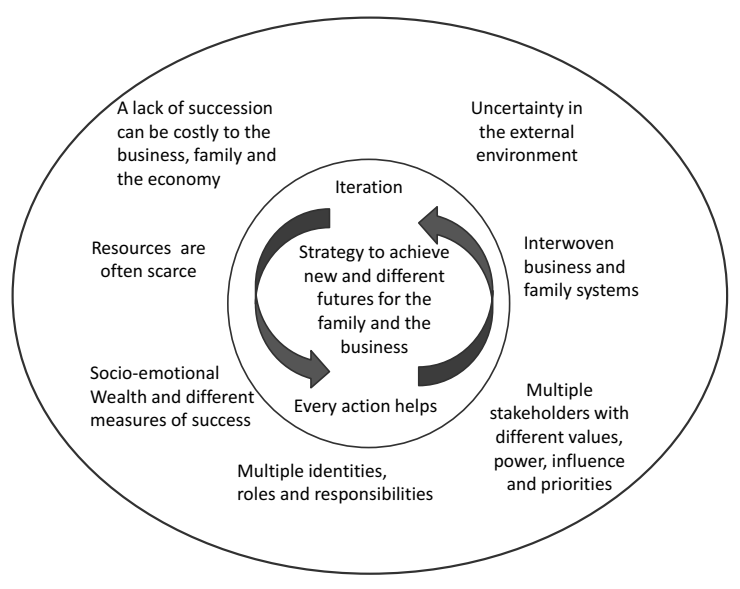

The framework draws attention to the pressures exerted by the external environment and the interaction between the interests of the family and business systems at play in a given context (Basco - Rodriguez, 2009). It recognises the differing power and influence of stakeholders including family members, non-family members, customers, suppliers, competitors and the community play in contributing to the wicked nature of the problem of succession whilst at the same time recognising the role that they may play in taming it. The notion of familiness is important to recognise in this context as it opens up a wicked dynamic in the family business context. A key characteristic of the nature of the problem of succession in a small family business are the multiple roles, responsibilities and identities of the family members which may change over time and influence strategy and decision making in the business and at home to varying degrees. A further characteristic is the role that socio-emotional wealth plays in strategy, planning and decision making as it is important to our understanding of both processes and measures of success in the family business context. Limited resources, including both financial and managerial, exert an influence on strategy in many small businesses where a lack of attention, knowledge or infrastructure to support succession strategy and the aligning of business and family interests may exist. Leadership and management capability and the apparent unwillingness of family businesses to 'professionalise' or to seek external advice clearly impact on the nature of strategic planning in this context. The framework also recognises the cost to the family, business and wider society that is the result of inefficient or ineffective family business succession that may be incurred. The framework is not exhaustive, however it does highlight the key character- 
istics of succession planning in a family business context that contribute to it being a wicked problem. In the following section we consider the implications of our analysis for practice and policy.

\section{Implications for practice and policy}

Many of the problems that small family businesses encounter are formidable, not straightforward to resolve and the strategies developed for succession are often not easy to recognise. Wicked Problems in the context of strategy for succession in small family businesses involve twists, turns, the unexpected, change, challenge, uncertainty and turbulence. Research typically suggests that well developed succession plans are a key to successful succession, particularly those that take into account the relationships between family members, the early preparation of successors and when family businesses engage in planning for wealth-transfer purposes (Morris et al., 1997). However, well developed plans appear to be a relatively rare occurrence in the wider small family business population (Jaffe, 2005). We argue that the reasons for this lie at least in part in the wicked nature of the problem and the process of formulating strategy for succession.

\section{Co-created strategy}

Whilst most strategy textbooks and teaching will focus on the business, formulating a succession plan for the family business requires much more than analysis of the external environment and determining business vision and direction. There is a growing recognition amongst academics, practitioners and business intermediaries of the need to work with the family prior to working with the business. It is argued that individual family members and the family as a whole must look at its own values - about generating wealth, spending or saving it, and how it wants to be remembered in the community (Jaffe, 2005). The strategy process also needs to consider ownership as well as management succession as they may occur together or at different times. In a review of the paths that connect next generation members with their family business, Nicholson and Bjornberg (2007) identify a range of choices and challenges associated with social and relational issues such as what measures need to be employed to encourage emotional attachment and avoid the possibility of damaging splits developing between family and non-family stakeholders during the succession planning process.

The concept of the wicked problem is powerful here and can help shed light on strategy that may influence practice in this context. It is not a case of a straight choice between prescriptive, emergent or adaptive approaches as they are not necessarily alternatives and there is al- ways likely to be some deliberate aspect to emergent and adaptive strategy and vice versa. At the heart of a strategic approach to succession in a small family business lies the involvement of family members and other stakeholders in decision making processes and the effective communication of the process and outcomes to all involved in the future of the business. A process of individual and collective learning appears to be a key aspect of solving wicked problems with much of that learning (at least in the initial stages) focused on what the actual problem is (Roberts, 2000). Communication and involvement of family and wider business stakeholders can help inform and better understand the complexity of the problem and ways in which it might be addressed although there may be a tendency for power and decision making to be concentrated amongst a select few in many small family businesses and the extent of an inclusive approach will be contingent upon specific circumstances. Camillus (2008) cautions against such groupthink in the taming of wicked problems and recommends the involvement of a wide range of stakeholders as one way in which this can be minimised. In the family business context this may include non-family members and trusted external advisors such as accountants or solicitors. Assumptions need to be questioned and future scenarios should inform the directions that small family businesses take in developing strategies for succession. To maintain and create a sense of family business identity it is important to hold on to and not lose sight of its purpose. Strategies for succession in small family businesses that seek to address wicked problems may of necessity entail some trial and error and a degree of experimentation as to what might work. As wicked problems change according to the solutions put forward to address them, their shape and form of the problem is never a constant. We argue that thinking about the problem of succession planning in this way leads to an alternative approach to strategy, founded on social planning processes to engage multiple stakeholders, understand hidden assumptions, to create a shared understanding of the problem and to foster a joint commitment to possible ways of resolving it.

The focus of much of the literature associated with confronting wicked problems suggests that a collaborative approach to strategy that leads to the formulation of a common, agreed approach in which the people who are affected also become participants in the solution is a key characteristic of an approach seeking to tame a wicked problem. This is far more preferable to more traditional authoritarian, top-down or competitive approaches to strategy development that still dominate thinking in some organisations and settings (Roberts, 2000). This would appear to be in tune with the interests of many small family businesses where the devel- 
opment of succession strategy requires the navigation of socially complex family and business systems where key actors may have multiple identities and roles. Roberts (op cit) also suggests that numerous, small scale solutions will create better system resilience and this finding has some resonance with the emergent and adaptive approach to strategy more generally adopted in smaller family enterprises as they seek to sustain the business and preserve family wealth. Several authors join Roberts in arguing for leadership approaches to address wicked problems that are more collaborative than authoritarian. For example Waddell et al. (2013) highlights the value of leadership capabilities in terms of facilitation, emotional intelligence and the ability to respect and understand many perspectives and viewpoints. This will undoubtedly represent a challenge for some practicing more authoritarian, directive or exclusive leadership styles. The nature and 'quality' of leadership and management and the role that professionalization plays in the development, growth and transition of small family enterprises remains a concern for some researchers and policy makers worthy of further investigation in the light of differing measures of success adopted by various external stakeholders.

\section{Implications for business support and intermediaries}

The wicked problem of family business succession has wider implications for business support policy at the regional, national and international levels. Policy makers tend to identify the absence of a succession plan as an indication of the lack of preparedness for succession. The empirical evidence is patchy and subject to selection bias as surveys are often based on samples of family firms that are clients of business intermediaries undertaking or sponsoring the research. However, a consistent picture of market failure in the form of a lack of formal planning for succession in family businesses emerges. For example, the Price Waterhouse Coopers Family Business survey reports that just thirteen per cent of businesses have a discussed and documented plan for succession (PWC, 2014). Institute for Family Business research suggests that about one third of family businesses are passed on to the second generation and one tenth reaches the third generation with the rest being closed or shut down (IFB, 2008). The sheer number of family businesses, their heterogeneity and familiness combined with the wicked nature of succession planning mean that they are not a primary target for many policy makers looking for relatively easy, high profile and quick wins. In a period of austerity in the public sector, policy makers are increasingly turning to the private sector to achieve wider social and economic benefits from their activ- ities and to draw on business networks to fill the gap that has emerged as a result of the reduction in public funds for business support.

An extensive literature identifies the important knowledge transfer role that intermediaries such as accountants, bankers and solicitors play in the development and sustainability of small businesses (e.g. Curran et al., 2000). At the same time, there is recognition that no single organisation can resolve wicked problems, thus making the interaction of multiple stakeholders imperative (Waddell et al., 2013). Many business intermediaries adopt intervention strategies that go beyond their core offering of financial or legal advice to offer specialist services aimed at family businesses. It is important these intermediaries recognise the wicked nature of the problem of succession and promote strategy processes that help to tame it to the benefit of the business, the family and the intermediary. This is not necessarily a simple or straightforward process and it takes time to build trust and confidence in relationships with multiple stakeholders. Family businesses may be understandably reluctant to open succession discussions with external stakeholders for a variety of personal and commercial reasons. They may regard succession as being 'too difficult', deferrable or not of immediate benefit or threat. Within the context of funding for family business growth, researchers have identified an 'empathy gap' between family business objectives and the institutional conditions attached to equity funding. This gap is based on the situation where financiers struggle to understand the family business model and adapt their funding offer to take greater account of family business finance preferences (Poutziouris, 2001). All intermediaries need to be aware of the need to adopt engagement strategies to overcome the empathy gap in order to connect with the world of the small family business. However, the extent to which business intermediaries have the incentives necessary to invest in approaches to build the trust necessary as a pre-cursor for discussion of succession issues with small family businesses is uncertain. Some of them are already equipped to offer the support for planning processes that engage multiple stakeholders, understand hidden assumptions, create a shared understanding of the problem and foster a joint commitment to possible ways of resolving it. They are also able to contribute to the implementation of such strategies through advice and guidance on a range of tax planning and employment issues, ownership, business sales, dispute resolution and mergers and acquisitions. Many larger family businesses will engage with services of this type however many of the smaller ones will be unable to afford these services or lack the necessary level of trust or belief in the value that they may realise to draw on them. 


\section{Conclusion}

The family business construct sets a number of constraints that impact on family business strategy for succession. The parameters that constrain as well as enable the workings of the family and of the business together with the challenges of the external environment create a wicked problem. Complexity and uncertainty around succession, the strategy process and the form the family and the business should take in the future pose significant challenges for strategy and succession in small family businesses. We suggest that this is best seen as a wicked problem that may be addressed in an incremental, collaborative and ongoing way to meet specific family and business issues. In this context the notion of emergent, adaptive strategy, founded upon emotions and relationships is particularly apposite for the unbounded world in which small family businesses and succession issues operate. Partial solutions to different aspects of the problem serve to deliver strategy options that can be tried and tested in the 'real world' characterised by messiness and change where there are no right or wrong answers only better and worse solutions.

Strategy for management and ownership succession in small family businesses requires degrees of consent and buy in by those immediately involved as well as wider stakeholders. However, part of the problem is that rather than consent there is in fact much dissent in the social settings as to the form, nature and direction of strategy and succession within the family and the business. Unbundling family from business and business from family frames what is undoubtedly a problem of wicked proportions. Where standard business strategy tools are used, they need to be supplemented with approaches that take into account of the influences and power of the family dimension that is part and parcel of the small family business equation. Leadership emphasising collaboration, emotional intelligence and facilitation has a key role to play in the taming of such wicked problems.

The future is there to be made in a resource-constrained environment and family businesses and their external stakeholders have the capacity, competence and capability to deliver a richer and more rewarding future for all. Within this challenge a clear way forward must surely be recognition of the problem itself though the evidence suggests that too many small family businesses do not recognise the need for succession planning or if they do, they do not take steps to develop the plans necessary to ensure succession. Many family businesses appear to put off or ignore planning for succession and developing networks to support the process. There are of course no straightforward, easy answers to matters that cannot necessarily be reconciled for mutu- al good of family or business. Structures, processes and relationships that regulate and help the small family business to succeed can also act against the interests of family and of business in matters related to succession. Strategy for succession in family business is by virtue of the many and varied challenges discussed wicked but far from being a negative recognising this can be a driver of change that can deliver a different future fit for the time and appropriate to the context.

Despite the nature of the uncertain environment in which small family business operate and in which strategy takes place, the future should be perceived as one offering hope and promise. Policy and practice can do so much and recognising the wicked problem of succession planning in small family businesses has to be a first step on the journey to delivering succession that is likely to succeed.

\section{References}

Arregle, J-L. - Naldi, L. - Nordquist, M. - Hitt, M.A. (2012): Internationalization of family-controlled firms: A study of the effects of external involvement in governance. Entrepreneurship Theory and Practice, 36(6), p. 1115-1143.

Ansoff, H.I. (1991): Critique of Henry Mintzberg's 'The Design School: Reconsidering the Basic Premises of Strategic Planning'. Strategic Management Journal, 12(6), p. 449-461.

Barnett, T. - Long, R. G. - Marler, L. E. (2012): Vision and exchange in intra-family succession. Effects on procedural justice climate among non-family managers. Entrepreneurship Theory and Practice, 36 (6), p. 1207-1225.

Barney, J. B. (1986): Organizational culture: Can it be a source of competitive advantage? Academy of Management Review, 11(3), p. 656-665.

Basco, R. - Rodriguez, M. J.P. (2009): Studying the family enterprise holistically: evidence for the integrated family and business systems. Family Business Review, 22(1), p. 82-95.

Batie, S. S. (2008): Wicked Problems and Applied Economics. American Journal of Agricultural Economics, 90 (5), p. 1176-1191.

Berrone, P. - Criz, C. - Gomez-Mejia, L. R. (2012): Socioemotional wealth in family firms: Thoeretical dimensions, assessment approaches and agenda for future research. Family Business Review, 25, p. 258-279.

Bigelli, M. - Sánchez-Vidal, J. (2012): Cash holdings in private firms. Journal of Banking \& Finance, 36(1), p. 26-35.

BIS (2013): Small Business Survey 2012. SME Employers: Focus of family businesses. Department for Business Innovation and Skills. May 2013 
Bjornberg, A. - Nicholson, N. (2012): Emotional Ownership: The Next Generation's Relationship with the Family Firm. Family Business Review, 25 (4), p. 374390.

Bloom, N. - Genakos, C. - Sadun, R. - Van Reenen, $J$. (2012): Management Practices Across Firms and Countries. Academy of Management Perspectives, 26 (1), p. 12-33.

Breton - Miller, L. - Miller, D. (2009): Agency vs. stewardship in public family firms: A social embeddedness reconciliation. Entrepreneurship Theory and Practice, 33 (6), p. 1169-1191.

Buchanan, R. (1992): Wicked Problems in Design Thinking. Design Issues, Vol. 8, No. 2 (Spring, 1992), p. 5-21. The MIT Press Stable URL: [online accessed May 2016] http://www.jstor.org/stable/1511637

Camillus, J. (2008): Strategy as a wicked problem. Harvard Business Review. May. [online accessed May 2016] http://www.induscommons.com/ files/102770262.pdf

Carney, M. (2005): Corporate governacnce and competitive advantage in family controlled firms. Entrepreneurship Theory and Practice, 29 (3), p. 249-265.

Chandler, A.D. (1962): Strategy and Structure: Chapters in the History of the Industrial Enterprise. Boston: MIT Press

Chrisman, J. J. - Chua, J. H. - Zahra, S. A. (2003): Creating wealth in family firms through managing resources: Comments and extensions. Entrepreneurship Theory and Practice, 27(4), p. 359-365.

Chrisman, J. J. - Steier, L. P. - Chua, J. H. (2008): Towards a theoretical basis for understanding the dynamics of strategic performance in family firms. Entrepreneurship Theory and Practice, 32 (6), p. 935947.

Chrisman, J. J. - Patel, P. J. (2012): Variations in R\&D investments of family and non-family firms. Behavioral agency and myopic loss aversion perspectives. Academy of Management Journal, 55 (4), p. 976-997.

Chua, J. H. - Chrisman, J. J. - Steier, L. P. - Rau, S.B. (2012): Sources of Heterogeneity in Family Firms: An Introduction. Entrepreneurship, Theory and Practice, November . 36 (6), p. 1103-1112.

Coyne (2004): Wicked Problems Revisited. Design Studies 26. [online accessed April 2016] DOI 10.1016/j.

Craig, J. - Moores, K. (2005): Balanced scorecards to drive the strategic planning of family firms, Family Business Review, Xviii (2), p. 105-122.

Cunningham, J. - Seaman, C. - McGuire, D. (2015): Knowledge Sharing in small family firms. A leadership perspective. Journal of Family Business Strategy, 7(1), p. 34-46.

Curran, J. - Rutherford, R. - Lloyd Smith, S. (2000): Is there a local business community? Explaining the non-participation of small business in local economic development. Local Economy, 15(2), p. 128-143.

Davis, P. S. - Harveston, P. D. (1999): In the founder's shadow: Conflict in the family firm. Family Business Review, 12, p. 311-323.

De Massis, A. - Chua, J. H. - Chrisman, J. J. (2008): Factors preventing intra-family succession. Family Business Review, 21, p. 183-199.

DeTienne D. R. - Chirico, F. (2013): Exit Strategies in Family Firms: How Socioemotional Wealth Drives the Threshold of Performance. Entrepreneurship Theory and Practice, 37(6), p. 1297-1318.

Dyck, B. - Mauws, M. - Starke, F.A. - Mischke, G. A. (2002): Passing the baton: The importance of sequence, timing, technique and communication in executive succession. Journal of Business Venturing, 17(2), p. 143-162.

Eddleston, K. A. - Kellermanns, F.W. - Floyd, S.W. Crittenden, V.L. - Crittenden, W.F. (2013): Planning for growth: Life stage differences in family firms. Entrepreneurship Theory and Practice, 37 (5), p. 11771202.

Frost, F. A. (2003): The Use of Strategic Tools by Small and Medium-Sized Enteprises: An Australasian Study. Strategic Change, 12, p. 49-62.

Gonzalez, M. - Guzman, A. - Pombo, C. - Trujillo, M. A. (2013): Family firms and debt: Risk aversion versus risk of losing control. Journal of Business Research, 66(11), p. 2308-2320.

Habbershon, T. G. - Williams, M. L. (1999): A resource based framework for assessing the strategic advantages of family firms. Family Business Review, 12, p. $1-25$.

Habbershon, T. - Williams, M. - MacMillan, I. C. (2003): A unified systems perspective of family firm performance. Journal of Business Venturing, 18(4), p. 451-465.

Horn, R. E. - Weber, R. P. (2007): New Tools For Resolving Wicked Problems. Mess Mapping and Resolution Mapping Processes. [online accessed April 2016] http://www.strategykinetics.com/New_Tools_ For_Resolving_Wicked_Problems.pdf

Hurst, D. K. (1995): Crisis and Renewal. Boston: Harvard Business School Press

IFB (2008): The UK Family Business Sector. A report by Capital Economics. London: Institute for Family BusinessIFB (2011): The UK Family Business Sector. Working to Growth the UK economy. A report by Oxford Economics. London: Institute for Family Business

Jaffe, D. T. (2005): Strategic planning for the family in business. Journal of Financial Planning, March, p. 50-56.

Jennings, P. - Beaver, G. (1997): The Performance and Competitive Advantage of Small Firms. A Manage- 
ment Perspective. International Small Business Journal, 15 (2), p. 63-75.

Johnson, G. - Melin, L. - Whittington, R. (2003): Guest Editors Introduction, Micro Strategy and Strategising: Towards an Activity Based View. Journal of Management Studies, 40 (1), p. 3-22.

Kellermanns, F. W. - Eddleston, K. A. - Barnett, T. Pearson, A. (2008): An exploratory study of family member characteristics and involvement: Effects on entrepreneurial behavior in the family firm. Family Business Review, 21(1), p. 1-14.

Kraus, S. - Harms, R. - Fink, M. - Pihkala, T. (2011): Family firm research: sketching a research field. International Journal of Entrepreneurship and Innovation Management, 13 (1), p. 32-47.

Lam, W. (2011): Dancing to two tunes: Multi-entity roles in the family business succession process. International Small Business Journal, 29 (5), p. 508-533.

Lansberg, I. S. (1988): The succession conspiracy. Family Business Review, 1 (2), p. 119-143.

Learned, E. P. - Christensen, C. R. - Andrews, K. R. Guth, W. D. (1965): Business Policy: Text and Cases. Homewood, Ill.: Irwin

Levinson, D. J. - Darrow, D. - Levinson, M. - Klein, K. B. - McKee, B. (1978): The Seasons of a Man's Life. New York: Knopf

Memili, E. - Chang, E. P. C. - Kellermanns, F. W. Welsh, D. H. B. (2013): Role conflicts of family members in family firms. European Journal of Work and Organizational Psychology, 24 (1), p. 143-151.

Miller, D. - Le Breton-Miller, I. (2003): Challenge versus advantage in family business. Strategic Organization, 1(1), p. 127-134.

Miller, D. - Le Breton-Miller, I. (2005): Managing for the long run: Lessons in competitive advantage from great family businesses. Boston: Harvard Business Press

Mitchell, J. R. - Hart, T. A. - Valcea, S. - Townsend, D. M. (2009): Becoming the Boss: Descretion and Post-Succession Success in Family Firms. Entrepreneurship: Theory and Practice, 33 (6), p. 1201-1218.

Mintzberg, H. (1973): Strategy Making in Three Modes. California Management Review, Vol. 16, No. 2, p. 4453.

Mintzberg, H. (1978): Patterns in Strategy Formation. Management Science, 24 (9), p. 934-948.

Morris, M. H. - Williams, R. O. - Allen, J. A. - Avila, $R$. A. (1997): Correlates of success in family business transitions. Journal of Business Venturing, 12 (5), p. 385-401.

Newell, A. - Simon, H. (1972): Human problem solving. Englewood Cliffs, NJ: Prentice-Hall Nicholson, N. Bjornberg, A. (2007): Ready, willing, Able? The next
Generation in Family Business. London: Institute for Family Business

Nordqvist, M. (2011): Understanding strategy processes in family firms: Exploring the roles of actors and arenas. International Small Business Journal, 30 (1), p. 24-40.

PWC (2014): Family Business Survey 2014. [Online accessed May 2016] http://www.pwc.co.uk/private-business-private-clients/the-key-uk-findings-from-thefamily-business-survey-2014.html

Poutziouris, P. Z. (2001): The Views of Family Companies on Venture Capital: Empirical Evidence from the UK Small to Medium-Size Enterprising Economy. Family Business Review, 14(3), p. 277-291.

Rittel, H. - Weber, M. (1973): Dilemmas in a general theory of planning. Policy Sciences, 4, p. 155-169.

Roberts, N. C. (2000): Wicked problems and network approaches to resolution. International Public Management Review, 1(1), p. 1-19.

Salvato, C. - Chirico, F. - Sharma, P. (2010): A farewell to the business: Championing exit and continuity in entrepreneurial family firms. Entrepreneurship \& Regional Development, 22(3-4), p. 321-348.

Selznick, P. (1957): Leadership in Administration: A Sociological Interpretation. Row, Petersen

Stavrou, E. T. - Swiercz, P. M. (1998): Securing the Future of the Family Enterprise: A Model of Offspring Intentions to Join the Business. Entrepreneurship: Theory and Practice, 23 (2), p. 19-39.

Termeer, C. - Dewulf, A. - Breeman, G. (2013): Governance of Wicked Climate Adaptation Problems. in: J. Knieling and W. Leal Filho (eds.) (2013): Climate Change Governance, Climate Change Management, DOI: 10.1007/978-3-642-29831-8_3, Springer-Verlag Berlin Heidelberg 2013

Waddell, S. - Mclachlan, M. - Dentoni, D. (2013): Learning \& Transformative Networks to Address Wicked Problems: A GOLDEN Invitation. International Food and Agribusiness Management Review, 16 (Special Issue A), p. 23-32.

Watson, T. J. (1994): In Search of Management: Culture, Chaos and Control in Managerial Work. London: International Thomson Business Press

Westhead, P. - Howarth, C. (2007): 'Types' of private family firms. An exploratory conceptual and empirical analysis. Entrepreneurship and Regional Development, 19(5), p. 405-431.

Wilson, N. - Wright, M. - Scholes, L. (2013): Family business survival and the role of boards. Entrepreneurship Theory and Practice, 37(6), p. 1369-1389.

Article arrived: June 2016.

Accepted: Sept. 2016. 